chose to recognize by inviting him to give a public "last lecture" reflecting on his years of service.

Epstein's rich scholarly career was supplemented by distinguished contributions to the governance of the university and of the profession. He held the chairmanship of the department for three years in the early sixties and then served as Dean of the College of Letters and Science at the end of that turbulent decade. A colleague remembers his job interview with Dean Epstein, Epstein peering transfixed through the curtains at massed student demonstrators on Bascom Hill while the young candidate sought to discourse convincingly about his dissertation and possible contribution to higher education at Wisconsin. It is striking that the years of challenge and turmoil on the campus never discouraged Epstein about students or academic life in general. He remained an optimist through the remaining decades of his career. Epstein was later offered the chancellorship of the university, but he turned it down to return to teaching.

During the 1970s Leon Epstein served as President of the Midwest Political Science Association. In the American Political Science Association he served as a member of the Council and Executive Committee and later as the national president in 1978-79. He has regularly been called upon for other professional tasks ranging from service as an external evaluator of political science departments around the country to chairing the APSA Committee on Graduate Education.

University and professional service never seemed to hinder Epstein's scholarly energies. He won numerous grants and fellowships, including a year at the Center for Advanced Study in the Behavioral Sciences, a Guggenheim Fellowship, a Social Science Research Council grant, and support from the Rockefeller Foundation, among others. Since 1981 he has been a fellow of the American Academy of Arts and Sciences. A roundtable in his honor, organized by Frank Sorauf, was held at the annual meeting of the American Political Science Association in Washington in September.

People who spoke at the retirement

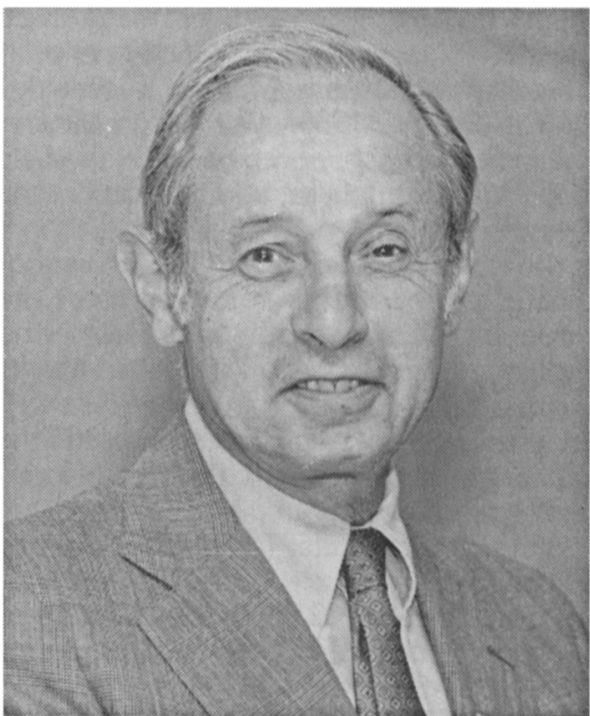

LEON EPSTEIN

party included Bernie Cohen, David Cronon, Peter Eisinger, David Fellman, Fred Harrington, Paul Herrnson, Clara Penniman, Nelson Polsby, Austin Ranney, Jorgen Rasmussen, and John Witte. Weighty matters concerning Epstein's intellectual and administrative contributions were given their proper due, but the talk was dominated by fondly recounted stories of Epstein's tennis passion, his love of convertibles, and his daily walks through the halls of North Hall.

After the retirement party and the end of the spring semester, Epstein moved his quarters to the Emeritus Office in North Hall. But colleagues have sensed no diminution of interest in political science or its local practitioners. He remains an active and important contributor to life on Wisconsin's Bascom Hill.

\section{Pool Papers and Data Available}

or others who may be doing research in his fields, much of the work of the late 
Ithiel de Sola Pool has been made available. Pool, professor of political science at the Massachusetts Institute of Technology who died in 1984, was a prolific researcher, author, and pioneer in the field of social and political communication and methods of analysis. ${ }^{*}$

Much of his work was left in various states of readiness for further use, with references as to people and places who can give further information as to its accessibility.

His widow, Jean, has compiled the following list of data which may be of interest to PS readers:

Papers and data from the following areas of research are in the MIT Archives, Cambridge, MA 02139. Helen Samuels or Donna Weber, Room $14 \mathrm{~N}-118$, phone (617) 253-5688, are in charge. Additional names indicate those people who have further information.

\section{Content Analysis}

Propaganda, symbols

The Operational Code of Classical Hinduism: Hypotheses and Topics of Interest Regarding Indian Elite Political Behavior. Complete data sets. Outline for study. Jean Pool, 105 Irving St., Cambridge, MA 02138.

\section{Content Nets}

Small World Study. Manfred Kochin, Mental Health Research Institute, University of Michigan, Ann Arbor, MI 48104.

\section{Simulation Studies}

Kennedy Election, Samuel Popkin, Department of Political Science, University of California, San Diego, La Jolla, CA 92093.

Mass Media Simulation Study, John Klensin, Research Scientist, MIT.

ADMINS: data management for simulation.

International relations simulation.

Communist communication simulation.

*For further information about Pool and his work, see "In Memoriam," Fall 1984 PS, p. 841.
Simulation technique to provide estimates of underlying data from aggregate results (shortwave broadcasts in USSR), John Klensin.

\section{Public Opinion in Foreign Policy}

The Trade Study: attitudes of business leaders toward foreign trade.

A code book, "American Business and International Trade Code Book \& Data, Free Press, 1960, Patrick Bova, NORC, University of Chicago, Johns Hopkins University Archives, Baltimore, MD 21218: Lewis Anthony Dexter's interviews.

\section{Vietnam Data}

Samuel Popkin, University of California, San Diego; Jean Pool.

\section{Communication Projects}

TV Audience Reaction to Violence: comparative U.S.-Japan data, Sumiko Iwao, Communications Research Institute, Keio University, Tokyo 108, Japan.

Information Flows: A Census of Information in Japan and U.S., Hiroshe Inose, National Center for Science Information Systems, Tokyo, Japan; Roger Hurwitz, Political Science Dept., MIT.

Communications needs for Egyptian rural development: survey research, Nazli Choucri, Political Science Dept., MIT; Ahmed Kamal, Dean, School of Engineering, and Ali Desouki, Sociology Dept., University of Cairo, Egypt.

Video tapes of discussion by early computer inventors of Eniac, IAS (von Neuman's group) Whirlwind, and IBM. Original groups were convened for two days of talk about their memories of inventing the early computers. These tapes, with the exception of the IBM discussion are at the Information Revolution Exhibit, Smithsonian Institution, c/o John Edlund, $\mathrm{Na}$ tional Museum of American History. The IBM tapes are held by Richard Solomon, Monson, MA 01057. 